\title{
Impact of integrated nutrient management on production potential of mungbean
}

\author{
Khalid Hussain ${ }^{1, *}$, Ayesha Ilyas ${ }^{1}$, Aftab Wajid ${ }^{1}$, Nasir Mehmood $^{2}$, Qamar Shakil ${ }^{3}$, Amina Ilyas $^{4}$, \\ Erdoğan Eşref Hakki ${ }^{5}$ and Thomas Hilger ${ }^{6}$
}

\author{
${ }^{1}$ Department of Agronomy, University of Agriculture, Faisalabad-Pakistan; ${ }^{2}$ Government College Women University, \\ Faisalabad-Pakistan; ${ }^{3}$ Fodder Research Sub-Station, Ayub Agricultural Research Institute, Faisalabad-Pakistan; ${ }^{4}$ Department \\ of Botany, Govt. College University, Lahore-Pakistan; ${ }^{5}$ Ziraat Fakültesi, Selçuk Üniversitesi -Konya Turkey; ${ }^{6}$ Institute of \\ Agricultural Sciences in the Tropics, University of Hohenheim Stuttgart-Germany \\ *Corresponding author's e-mail: Khalid.hussain@uaf.edu.pk
}

\begin{abstract}
Mungbean is one of the important grain legume crops in Pakistan due to its vigorous growth even in adverse environment. Mungbean is part of daily cuisine in the country but its production is low mostly due to imbalance fertilization. The study was carried out to find best combination of nitrogen $(\mathrm{N})$, phosphorus $(\mathrm{P})$ and potassium $(\mathrm{K})$ for maximum production under less fertile soils during 2017-2018. In this study, three combinations of NPK (i.e., 30:30:0, 30:60:0 and 30:60:30 $\mathrm{kg} \mathrm{ha}^{-1}$ ) were compared with control (without fertilization). Maximum pods per plant $(22.43)$, pod length $(9.51 \mathrm{~cm})$, seeds per pod (8.97), 1000 seed weight $(44.07 \mathrm{~g})$, seed yield $\left(1163 \mathrm{~kg} \mathrm{ha}^{-1}\right)$, biological yield $\left(5231 \mathrm{~kg} \mathrm{ha}^{-1}\right)$ and harvest index $(24.63 \%)$ were obtained from 30:60:30 kg NPK ha-1 during 2017 and similar trends were found during 2018. Maximum leaf area duration (212.64, 215.09 days), crop growth rate $\left(3.99,4.02 \mathrm{~g} \mathrm{~m}^{-2} \mathrm{~d}^{-1}\right)$, net assimilation rate $\left(2.46,2.54 \mathrm{~g} \mathrm{~m}^{-2} \mathrm{~d}^{-1}\right)$ and fraction of intercepted radiation $\left(0.89,0.88 \mathrm{MJ} \mathrm{m}^{-2}\right)$ were obtained from mungbean plant under 30:60:30 $\mathrm{kg} \mathrm{ha}^{-1} \mathrm{NPK}$ application during 2017 and 2018 , respectively. These results are suggesting that integrated application of nitrogen, phosphorous and potash is very imperative to attain higher production of mungbean under semi-arid environments. It is concluded from the findings that farmers can harvest maximum final outputs of mungbean by the application of 30:60:30 $\mathrm{kg} \mathrm{ha}^{-1} \mathrm{NPK}$, respectively.

Keywords: Growth analysis, Radiation interception, Fertilizer application, Sustainable legume production, Semi-arid environment.
\end{abstract}

\section{INTRODUCTION}

Mungbean (Vigna radiata L.) is a member of family Fabaceae, belonging to genus Vigna, and species radiate; it is pulse crop and often known as green gram (Shil and Bandopadhyay, 2007). Mungbean production rate was 0.13 million tons during 2016-2017 and 0.178 million ha area was used to cultivate mungbean in Pakistan (Government of Pakistan, 2017). Mungbean is an important pulse crop in Pakistan and other Asian countries (Hussain et al., 2006) due to its vigorous growth under a wide range of environmental conditions. Mungbean is a kharif crop and the most popular pulse among common farmers of the Pakistan (Khattak et al., 2004). Because of more nutritive importance mungbean is known as a supper food for infants and patients (Hozayn et al., 2007). Mungbean has capacity to create a mutual association with particular microbes, fixing biological nitrogen in root nodules that provides nitrogen to plants
(Mandal et al., 2009; Mahmood and Athar, 2008). The grains of mungbean has $3.7 \%$ ash, $0.6 \%$ fat, and $0.9 \%$ fiber (Malik, 1994). Mungbean is also rich source of vitamins (A, B1, B2, $\mathrm{C}$ etc? and essential minerals ( $\mathrm{Fe}, \mathrm{P}, \mathrm{K}, \mathrm{Ca})$. Mungbean seeds are used in the synthesis of noodles, soups, desserts, curries, sweets, snacks, bean sprouts and also used as dahl in Pakistan. Mungbean production is low in Pakistan mainly due to low soil productivity, low seed rate, attack of diseases, unbalance use of fertilizers and poor agronomic practices (Ansari et al., 2000). The common but wrong perception among farmers is that mungbean being a legume crop does not need fertilizers and generally cultivated on the peripheral lands without using fertilizers. Fertilizers are beneficial for crop production (Hoque et al., 2004; Singh et al., 2013) and maximum seed yield can be achieved by balance use of fertilizers. However, it is dependent on other factors like cultivars. Mungbean varieties act differently in term of yield and development under adaptable climatic conditions. The use of high yielding

Hussain, K, A. Ilyas, A. Wajid, N. Mehmood, Q. Shakil, A. Ilyas, E.E. Hakki and T. Hilger.2021. Impact of integrated nutrient management on production potential of mungbean. Pak. J. Agri. Sci.58:1123-1130.

[Received 1 Jun 2021; Accepted 17 Jun 2021; Published (online) 21 Sep. 2021] 
varieties and balance use of fertilizers is significant to improve the production rate of mungbean crop. High yielding mungbean varieties must have more leaf area index (LAI), net assimilation rate (NAR) at vegetative phase, crop growth rate (CGR) and total dry matter (TDM) production at all development phases that increase the yield and yield related parameters of mungbean crop (Mondal et al., 2011). Pakistan lies in arid to semi-arid condition with low precipitation which directly affects crop production. The objective of current study was to optimize the balance amount of fertilizer application for sustainable mungbean production under semiarid conditions.

\section{MATERIALS AND METHODS}

Site description: The field research was conducted at Agronomic research farm, University of Agriculture, Faisalabad for two consecutive year 2017 and 2018 in first week of July. Before the sowing of crop, samples of soil from experimental site were taken with the help of auger from $30 \mathrm{~cm}$ depth. These soil samples were examined to check the physicochemical properties of soil. Detail of soil physicochemical analysis is depicted in Table 1. The experimental area received maximum $\left(42^{\circ} \mathrm{C}\right)$ temperature in July and minimum $\left(20^{\circ} \mathrm{C}\right)$ temperature in October. Total rainfall $(218.8 \mathrm{~mm})$ was observed during the whole season. The highest quantity of rainfall (54\%) was recorded during the month of July, while $30 \%$ of total rainfall was observed during the month of August and $16 \%$ of the total rainfall was noted during the month of September. However, no rainfall was recorded during the mid of October (Fig. 1).

Experimental setup: The trial was comprised of following treatments of nitrogen $(\mathrm{N})$, phosphorous $(\mathrm{P})$ and Potash $(\mathrm{K})$ (NPK kg per hectare).

$\mathrm{T}_{1}$ : Control (without fertilization)

$\mathrm{T}_{2}: 30,30,0$

$\mathrm{T}_{3}: 30,60,0$

$\mathrm{T}_{4}: 30,60,30$

Table 1. Physicochemical analysis of soil samples collected from the study site

\begin{tabular}{ccccccccccc}
\hline $\begin{array}{c}\text { Soil } \\
\text { depth }\end{array}$ & $\begin{array}{c}* \text { Soil } \\
\text { texture }\end{array}$ & $\begin{array}{c}\text { Sand } \\
(\boldsymbol{\%})\end{array}$ & $\begin{array}{c}\text { Silt } \\
(\boldsymbol{\%})\end{array}$ & $\begin{array}{c}\text { Clay } \\
(\boldsymbol{\%})\end{array}$ & $\begin{array}{c}* \mathbf{p H} \\
{ }^{*} \text { SOC } \\
\left(\mathbf{g ~ k g}^{-1}\right)\end{array}$ & $\begin{array}{c}* \text { Total N } \\
(\boldsymbol{\%})\end{array}$ & $\begin{array}{c}\text { Extractable P P } \\
\left(\mathbf{m g ~ k g}^{-1}\right)\end{array}$ & $\begin{array}{c}\text { Extractable K } \\
\left(\mathbf{m g ~ k g}^{-1}\right)\end{array}$ & $\begin{array}{c}\text { BD } \\
\left(\mathbf{g ~ c m}^{-3}\right)\end{array}$ \\
\hline $0-30 \mathrm{~cm}$ & Loamy soil & 45 & 38 & 16 & 7.62 & 13 & 0.051 & 7.13 & 177.9 & 1.8 \\
\hline
\end{tabular}

*Soil texture was measured by pipette method, $\mathrm{pH}$ as soil: water $=1: 1, \mathrm{SOC}=$ soil organic carbon measured by Walkley-Black method, Total nitrogen was measured by Kjeldahl and steam distillation method, Extractable P by Bray II method, Extractable $\mathrm{K}_{\text {by }} 1 \mathrm{~N} \mathrm{NH}_{4} \mathrm{OAc}$ and $\mathrm{BD}=$ bulk density by core methods

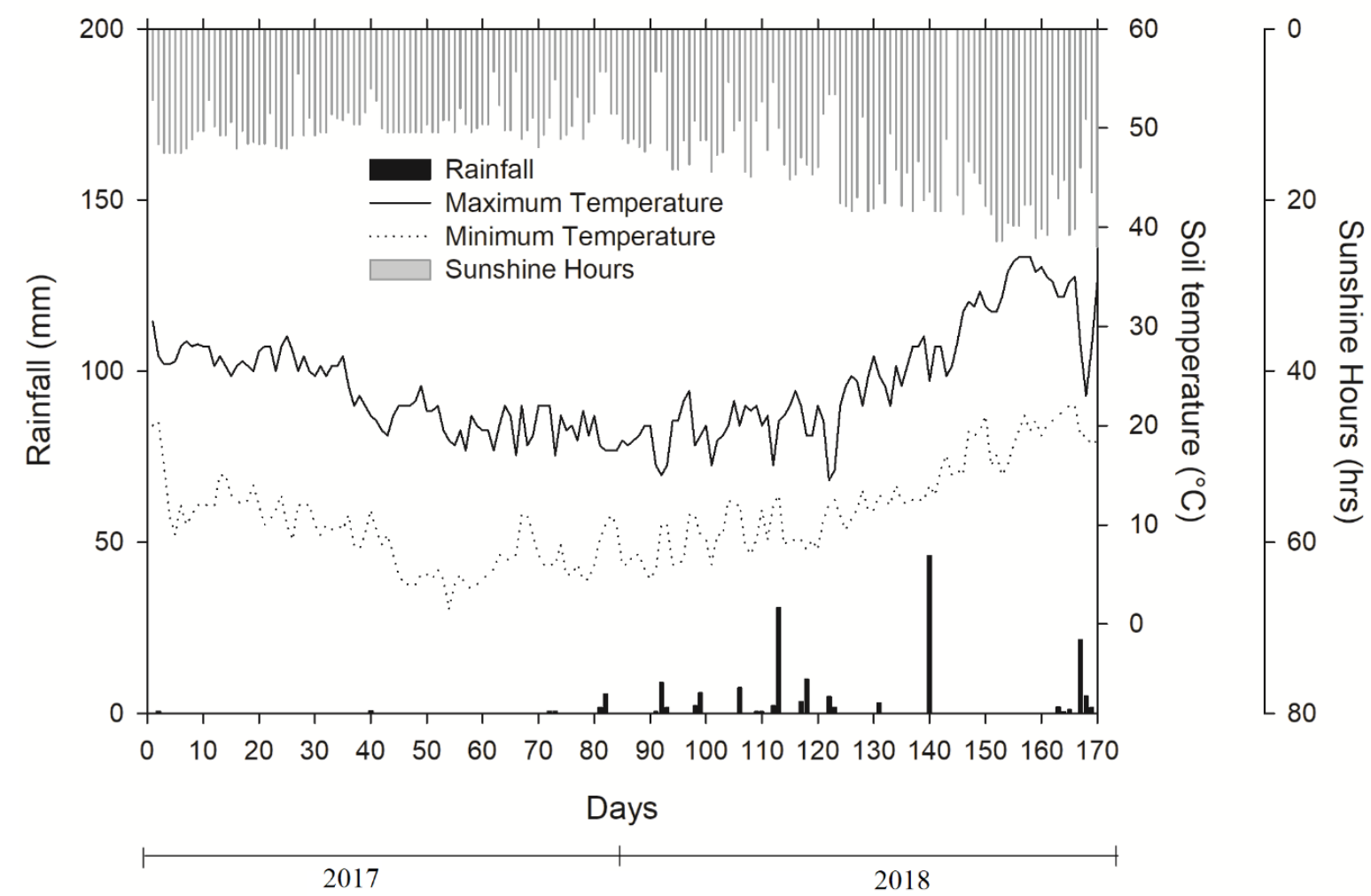

Figure 1. Maximum and minimum temperature $\left({ }^{\circ} \mathrm{C}\right)$ and rainfall $(\mathrm{mm})$ of study site during the crop growing season 
The mungbean cv. Azri-2011 was obtained from Ayub Agriculture Research Institute, Faisalabad. The seed rate for crop sowing was $10 \mathrm{~kg}$ per hectare. The sowing was done on well prepared seedbed with proper soil moisture. Phosphorus and potassium fertilization were done at sowing while two splits of nitrogen fertilizer were used, one at the time of sowing while other half with first irrigation (30 days after palnting). Urea and DAP were used as source of nitrogen while phosphorus and potassium fertilizer sources were DAP and SOP, respectively. Crop received three irrigations i.e at emergence, at blooming stage and at the time of pod development.

\section{Observations and measurements}

Leaf area index (LAI) and above ground dry biomass: For monitoring growth of the crop, the leaf area and above ground dry biomass was measured 5 times along cropping season and thereafter leaf area index was measured by using Hunt, 1978 procedure:

$$
\text { Leaf area index }=\frac{\text { Crop leaf area }}{\text { Crop covered area }}
$$

Leaf area duration $(\boldsymbol{L A D})$ : LAD represents the time leaf remained green or photo-synthetically active. Each crop LAD was measured along the growing season with following formula as estimated by Hunt (1978):

$$
L A D=\frac{(L A I 1+L A I 2) \times(\text { Time of LAI 2 - Time of LAI1 })}{2}
$$

Where $L A I_{l}$ is leaf area index measured from $1^{\text {st }}$ sampling and so on.

Crop growth rate (CGR): The growth rate of a crop at any time is called as crop growth rate (CGR). CGR $\left(\mathrm{g} \mathrm{m}^{-2} \mathrm{~d}^{-1}\right)$ was calculated for each crop during the growing season with the Hunt (1978) formula:

$$
C G R=\frac{T D M 2-T D M 1}{T 2-T 1}
$$

Where $\mathrm{TDM}_{1}$ and $\mathrm{TDM}_{2}$ are the sample above ground dry biomass at times $\mathrm{T}_{1}$ and $\mathrm{T}_{2}$, respectively.

Net assimilation rate (NAR): It is the net dry matter production after respiration losses. NAR $\left(\mathrm{g} \mathrm{m}^{-2} \mathrm{~d}^{-1}\right)$ was calculated for each crop with the Hunt (1978) formula:

$$
N A R=\frac{\text { Total above ground dry biomass at final harvest }}{\text { Final leaf area duration (LAD) }}
$$

Fraction of intercepted photosynthetically active radiations $(\boldsymbol{f P A R}):$ PPAR is the fraction of the incoming solar radiation absorbed by the plant, typically describing the light absorption across an integrated plant canopy and was calculated as

$$
f \text { PAR }=1-\frac{P A R_{b c}\left(M J m^{-2}\right)}{P A R_{a c}\left(M J m^{-2}\right)}
$$

where PAR Pac $_{\text {is }}$ PAR above crop canopy and PAR bc $_{\text {in }}$ PAR below crop canopy (SunScan Canopy analyzer was used for PAR measurements above and below crop canopy during the cropping season).

Yield and yield parameters: Yield and yield parameters data were collected at the time of crop harvest. Crop was harvested on $13^{\text {th }}$ and $15^{\text {th }}$ October 2017 and 2018 , respectively when 90 $\%$ of pods were mature. After harvesting, the crop was secured tightly into bundles allowed to dry about ten days to bring down the grain moisture level up to $12 \%$ for final yield and yield component calculation. For calculating the yield parameters, ten plants were selected from each plot randomly. The measured yield parameters were no. of pods, pod length (cm), seeds per pod and plant, 1000 seed weight $(\mathrm{g})$. Moreover, whole plot including above mentioned ten plants were used to calculate the seed yield $\left(\mathrm{kg} \mathrm{ha}^{-1}\right)$, biological yield $\left(\mathrm{kg} \mathrm{ha}^{-1}\right)$ and harvest index (HI). At the end per plot yield was converted into per ha yield accordingly then their averages from three replication was calculated. The HI was calculated with following formula:

$$
\text { Harvest Index }(\%)=\frac{\text { Economic }(\text { grain }) \text { yield }}{\text { Biological yield }} \times 100
$$

Statistical analysis: Statistical anlaysis software (SAS v.9) was used for statistical analysis. Randomized complete block design (RCBD) with three replications was used under field condition and statistical analysis. Analysis of variance was used for statistical significancy at 5\% probability level. Later treatment means were compared with Tukey test.

\section{RESULTS}

Leaf area index (LAI): Significant variations $(p \leq 0.05)$ in LAI of mungbean during both growth periods were observed by the application of different nutrient combination (Fig. 2). A linear increase was observed after 15 days up to 60 days, thereafter, a decline in LAI was observed from 70 to 90 days in all the treatments. The $\mathrm{T}_{4}\left(30,60,30 \mathrm{NPK} \mathrm{kg} \mathrm{ha}{ }^{-1}\right)$ performed comparatively better over other treatments. The maximum LAI (3.49) was recorded from $\mathrm{T}_{4}$ at 60 days after sowing of the crop in comparison with all other treatments while minimum LAI (3.06) was found in plants where no fertilizers was applied (control) during 2017. Similar trends of leaf area index were observed during 2018 but the leaf area index was higher as compared to 2017.

Above ground total dry biomass (TDM): A linear increase in above ground total dry biomass/matter (TDM) production was observed in all treatments during both growing seasons (Fig. 3). Maximum TDM was observed at 90 days after planting (DAP), while minimum TDM was observed at 15 DAP. It is indicated that application of balanced NPK had significantly affected total dry matter of mungbean not only during growing period but also at harvest. The maximum TDM (1261.3 $\mathrm{g} \mathrm{m}^{-2}$ ) was recorded in mungbean treated with $30,60,30 \mathrm{NPK} \mathrm{kg} \mathrm{ha}^{-1}\left(\mathrm{~T}_{4}\right)$ while the minimum TDM (1048.5 $\mathrm{g} \mathrm{m}^{-2}$ ) was observed in control treatment where no fertilizer was applied to the crop (T1) during 2017 growing season.

During 2018, the crop dry biomass production over the growing season of the crop was higher as compared to 2017. All treatments produced higher total dry matter till harvest following similar trend as observed during 2017. Maximum 


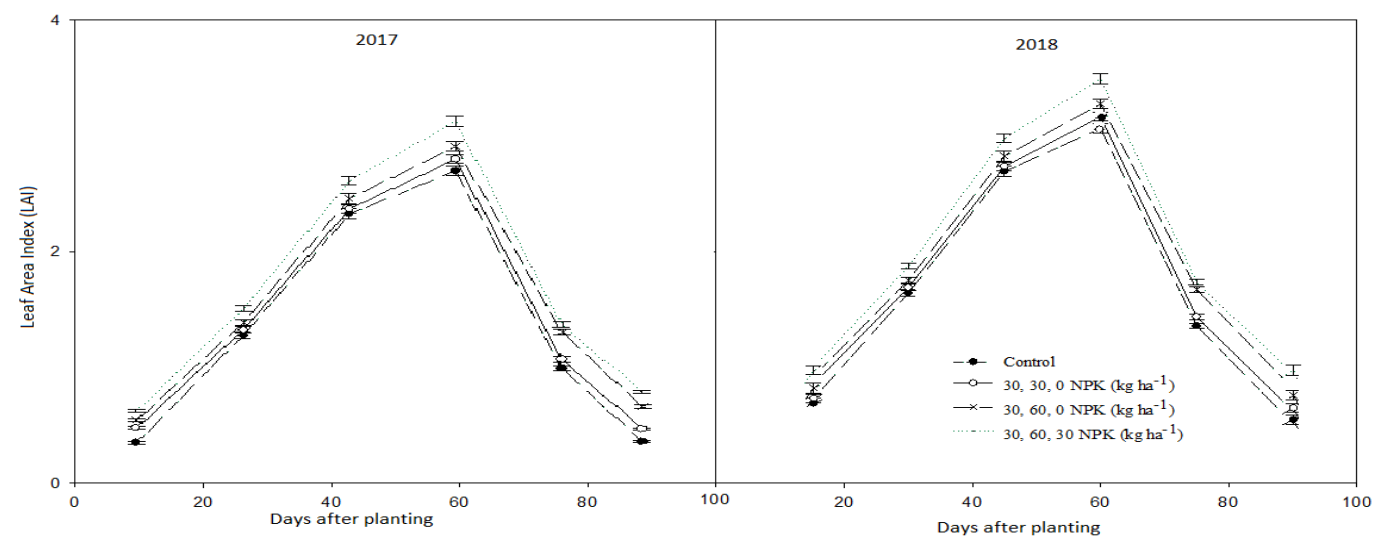

Figure 2. Temporal changes in leaf area index (LAI) of mungbean influenced by various nutrients levels.

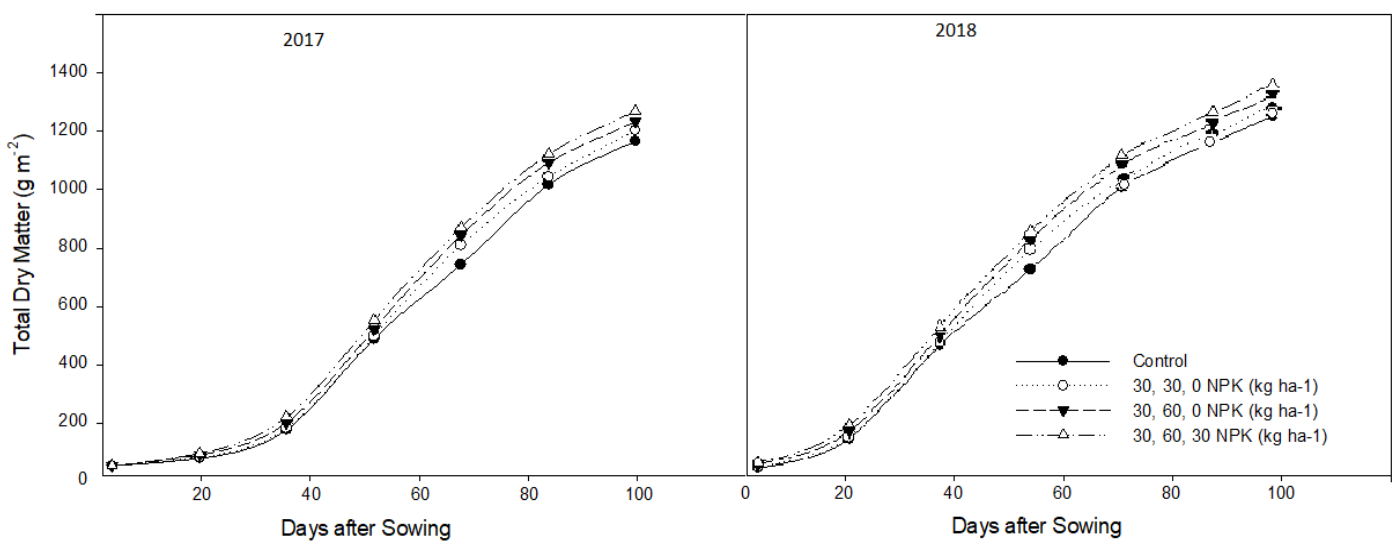

Figure 3. Temporal variation in total dry matter production in mungbean influenced by various nutrients levels.

TDM $\left(1321.5 \mathrm{~g} \mathrm{~m}^{-2}\right)$ was obtained from the treatment where $30,60,30 \mathrm{~kg} \mathrm{NPK} \mathrm{ha}^{-1}$ fertilizer was applied to the crop. Minimum dry matter production $\left(1180.9 \mathrm{~g} \mathrm{~m}^{-2}\right)$ was observed in the control treatment where no fertilizer applied to the crop. Leaf area duration $(\boldsymbol{L A D})$ : The effect of various nutrient levels was statistically significant $(p \leq 0.05)$ on leaf area duration during 2017 while the results were statistically not significant during 2018 (Table 2). During 2017, highest cumulative LAD (212.64 days) was measured in mungbean where 30, 60, $30\left(\mathrm{NPK} \mathrm{kg} \mathrm{ha}{ }^{-1}\right)$ fertilizer was applied while lowest cumulative leaf area duration of 200.92 days were obtained from mungbean with no fertilizer application (T1). Whereas, the results indicated statistically non-significant effect on leaf area duration during 2018.

Crop growth rate (CGR): The impact of fertilizer application on mean crop growth rate was statistically significant during both studied year (Table 2). During 2017, highest mean CGR $\left(3.99 \mathrm{~g} \mathrm{~m}^{-2} \mathrm{~d}^{-1}\right)$ was recorded in mungbean treated with 30 , 60, 30 (NPK kg ha-1) while lowest CGR of $2.96 \mathrm{~g} \mathrm{~m}^{-2} \mathrm{~d}^{-1}$ was measured in control treatment where no fertilizer was applied. Whereas, during 2018, maximum value of CGR $\left(4.02 \mathrm{~g} \mathrm{~m}^{-2}\right.$ $\mathrm{d}^{-1}$ ) was recorded in mungbean treated with $30,60,30$ (NPK $\mathrm{kg} \mathrm{ha}^{-1}$ ) while minimum mean CGR of $3.05 \mathrm{~g} \mathrm{~m}^{-2} \mathrm{~d}^{-1}$ was obtained in control treatment where no fertilizer was applied to the crop.

Net assimilation rate (NAR): The effect of fertilizer applied in various combination was statistically significant $(p \leq 0.05)$ on net assimilation rate in mungbean crop during both growing seasons (Table 2). During 2017, highest net assimilation rate $2.46 \mathrm{~g} \mathrm{~m}^{-2} \mathrm{~d}^{-1}$ was measured in $\mathrm{T} 4$ where fertilizer was applied at the rate of 30,60, $30\left(\mathrm{NPK} \mathrm{kg} \mathrm{ha}{ }^{-1}\right)$ while minimum net assimilation rate $1.97 \mathrm{~g} \mathrm{~m}^{-2} \mathrm{~d}^{-1}$ was obtained from control treatment where no fertilizer was applied.

During 2018 growing season, mean maximum net assimilation rate $2.54 \mathrm{~g} \mathrm{~m}^{-2} \mathrm{~d}^{-1}$ was computed from T4 having fertilization at the rate of $30,60,30\left(\mathrm{NPK} \mathrm{kg} \mathrm{ha}{ }^{-1}\right)$ whereas, minimum net assimilation rate $1.98 \mathrm{~g} \mathrm{~m}^{-2} \mathrm{~d}^{-1}$ was measured in control treatment where no fertilization was done.

Fraction of intercepted photosynthetically active radiations $(\boldsymbol{f P A R})$ : The variation in fraction of intercepted photosynthetically active radiations during both growing seasons was statistically significant $(p \leq 0.05)$ in mungbean crop as effected by various fertilizer combinations (Table 2). During 2017, maximum fPAR $\left(0.89 \mathrm{MJ} \mathrm{m}^{-2}\right)$ was computed in mungbean with fertilizer application at the rate of 30,60 , 
30 (NPK kg ha ${ }^{-1}$ ) while minimum fraction of PAR was intercepted in T1 without fertilization. During 2018 growing period, highest PAR $\left(0.88 \mathrm{MJ} \mathrm{m}^{-2}\right)$ was intercepted in mungbean with $30,60,30$ (NPK kg ha-1) fertilizer application whereas, lowest quantity of PAR was intercepted by mungbean planted under no fertilizer application treatment.

Table 2. Leaf area duration (LAD), mean crop growth rate (CGR), net assimilation rate (NAR) and fraction of intercepted radiation ( $f$ IPAR) in mungbean influenced by various nutrients levels.

\begin{tabular}{|c|c|c|c|c|}
\hline Treatments & $\begin{array}{l}\text { LAD } \\
\text { (days) }\end{array}$ & $\begin{array}{c}\text { Mean } \\
\text { CGR (g } \\
\left.\mathbf{m}^{-2} \mathbf{d}^{-1}\right) \\
\end{array}$ & $\begin{array}{c}\text { NAR } \\
\left(\text { g m }^{-2}\right. \\
\left.d^{-1}\right) \\
\end{array}$ & $\begin{array}{c}f \text { IPAR } \\
\left(\mathbf{M J ~ m}^{-2}\right)\end{array}$ \\
\hline \multicolumn{5}{|l|}{2017} \\
\hline $\begin{array}{l}\text { T1= Control (no } \\
\text { fertilization) }\end{array}$ & $200.92 \mathrm{c}$ & $2.96 \mathrm{c}$ & $1.97 \mathrm{~b}$ & $0.54 \mathrm{c}$ \\
\hline $\begin{array}{l}\mathrm{T} 2=30,30,0(\mathrm{NPK} \mathrm{kg} \\
\left.\mathrm{ha}^{-1}\right)\end{array}$ & $207.72 b$ & $3.80 \mathrm{~b}$ & $2.15 b$ & $0.68 b$ \\
\hline $\begin{array}{l}\text { T3 = 30, 60, } 0(\mathrm{NPK} \mathrm{kg} \\
\left.\mathrm{ha}^{-1}\right)\end{array}$ & $210.41 \mathrm{ab}$ & $3.92 \mathrm{ab}$ & $2.39 \mathrm{a}$ & $0.70 \mathrm{~b}$ \\
\hline $\begin{array}{l}\mathrm{T} 4=30,60,30(\mathrm{NPK} \\
\left.\mathrm{kg} \mathrm{ha}^{-1}\right)\end{array}$ & $212.64 \mathrm{a}$ & $3.99 \mathrm{a}$ & $2.46 \mathrm{a}$ & $0.89 a$ \\
\hline$L S D$ & 4.68 & 0.18 & 0.28 & 0.13 \\
\hline \multicolumn{5}{|l|}{2018} \\
\hline $\begin{array}{l}\text { T1= Control (no } \\
\text { fertilization) }\end{array}$ & 203.33 & $3.05 \mathrm{c}$ & $1.98 \mathrm{~b}$ & $0.58 \mathrm{bc}$ \\
\hline $\begin{array}{l}\mathrm{T} 2=30,30,0(\mathrm{NPK} \mathrm{kg} \\
\left.\mathrm{ha}^{-1}\right)\end{array}$ & 209.00 & $3.76 b$ & $2.14 b$ & $0.66 \mathrm{~b}$ \\
\hline $\begin{array}{l}\text { T3 =30, 60, } 0(\mathrm{NPK} \mathrm{kg} \\
\left.\mathrm{ha}^{-1}\right)\end{array}$ & 211.06 & $3.93 \mathrm{ab}$ & $2.37 \mathrm{a}$ & $0.75 \mathrm{ab}$ \\
\hline $\begin{array}{l}\mathrm{T} 4=30,60,30(\mathrm{NPK} \\
\left.\mathrm{kg} \mathrm{ha}^{-1}\right)\end{array}$ & 215.09 & $4.02 \mathrm{a}$ & $2.54 \mathrm{a}$ & $0.88 \mathrm{a}$ \\
\hline$L S D$ & $N S$ & 0.24 & 0.21 & 0.15 \\
\hline
\end{tabular}

Means followed by different small letters within column indicate significant differences between the treatments.

Yield and yield parameters: Analysis of variance showed that impact of synthetic fertilizers on pods per plant was statistically significant $(p \leq 0.05)$ during both growing seasons (Table 2). Maximum number of pods per plant (22.43) were recorded from $\mathrm{T}_{4}\left(30,60,30 \mathrm{NPK} \mathrm{kg} \mathrm{ha}^{-1}\right)$ while low numbers of pods per plant (15.90) were observed in plants where no fertilizers was applied (control) during 2017. whereas, during 2018 growing season the number of pods per plant slightly increased. During 2018, statistically highest pods per plant were obtained from the plants received $30,60,30 \mathrm{~kg} \mathrm{ha}^{-1} \mathrm{NPK}$ (T4) while statistically minimum pods number (16.90) were obtained from control treatment.

Effects of mineral nutrition on crop pod length was statistically non-significant during 2017 whereas the results were significantly higher in 2018. During 2018, pod length $(9.88 \mathrm{~cm})$ was recorded from $\mathrm{T}_{4}\left(30,60,30 \mathrm{NPK} \mathrm{kg} \mathrm{ha}{ }^{-1}\right)$ while small pods were observed in plants where no fertilization was done.

Moreover, the impact of mineral nutrition on seeds per pod was also statistically significant during both years of the study (Table 2). The highest no. of seeds per pod (8.97) were recorded in $\mathrm{T}_{4}\left(30,60,30 \mathrm{NPK} \mathrm{kg} \mathrm{ha}{ }^{-1}\right)$ as compared with rest of treatments while minimum seeds $\operatorname{pod}^{-1}$ (6.76) were observed in plants where no fertilization was done (control) during 2017 growing season. In 2018, maximum seeds per pod (9.65) were recorded in $\mathrm{T}_{4}\left(30,60,30 \mathrm{NPK} \mathrm{kg} \mathrm{ha}{ }^{-1}\right)$ as compared with rest of treatments while minimum seeds pod ${ }^{-1}$ (6.76) were observed in plants where no fertilization was done (control).

The fertilizer combination statistically effected 1000-seed weight $(\mathrm{g})$ of mungbean during both growing seasons (Table 2). During 2017, the maximum 1000-seed weight (44.07 g) was recorded from $30,60,30 \mathrm{NPK} \mathrm{kg} \mathrm{ha-1} \mathrm{treatment}$ closely followed by $30,60,0 \mathrm{NPK} \mathrm{kg} \mathrm{ha}{ }^{-1}$ treatment. The lowest weight $(30.31 \mathrm{~g}$ ) of 1000 seeds was found in plants where no fertilization was done. The 2018 data indicated that the maximum 1000 -seed weight $(45.99 \mathrm{~g})$ was recorded from treatment where $30,60,30 \mathrm{NPK} \mathrm{kg} \mathrm{ha}{ }^{-1}$ was applied to the mungbean crop. The lowest weight $(31.00 \mathrm{~g})$ of 1000 seeds was found in plants where no fertilization was done.

The impact of synthetic fertilizers on seed yield was statistically significant during both study years (Table 3). During 2017, highest seed yield $\left(1163 \mathrm{~kg} \mathrm{ha}^{-1}\right)$ was receded from $\mathrm{T}_{4}$ where $30,60,30 \mathrm{NPK} \mathrm{kg} \mathrm{ha}^{-1}$ was applied while lowest seed yield $\left(729 \mathrm{~kg} \mathrm{ha}^{-1}\right)$ was observed in plants where, no fertilizers was applied (control). Results of 2018 growing season revealed maximum seed yield (1271 $\left.\mathrm{kg} \mathrm{ha}^{-1}\right)$ in treatment where $30,60,30 \mathrm{NPK} \mathrm{kg} \mathrm{ha}{ }^{-1}$ was applied while minimum seed yield ( $834 \mathrm{~kg} \mathrm{ha}^{-1}$ ) was observed in plants where, no fertilizers was applied (control).

Table 3. Number of pods per plant, pod length, number of seeds per pod and 1000 seed weight in mungbean influenced by various nutrients levels.

\begin{tabular}{|c|c|c|c|c|}
\hline Treatments & $\begin{array}{l}\text { Pods } \\
\text { /plant }\end{array}$ & $\begin{array}{l}\text { Pod } \\
\text { length } \\
\text { (cm) }\end{array}$ & $\begin{array}{l}\text { Seeds } \\
\text { /pod }\end{array}$ & $\begin{array}{l}\text { 1000-seed } \\
\text { weight }(\mathrm{g})\end{array}$ \\
\hline \multicolumn{5}{|l|}{2017} \\
\hline $\begin{array}{l}\mathrm{T} 1=\text { Control (no } \\
\text { fertilization) }\end{array}$ & $15.90 \mathrm{~d}$ & 7.96 & $6.76 \mathrm{c}$ & $30.31 \mathrm{c}$ \\
\hline $\begin{array}{l}\mathrm{T} 2=30,30,0(\mathrm{NPK} \\
\left.\mathrm{kg} \mathrm{ha}^{-1}\right)\end{array}$ & $17.62 \mathrm{c}$ & 8.38 & $7.72 b$ & $38.08 \mathrm{~b}$ \\
\hline $\begin{array}{l}\text { T3 =30, 60, } 0(\mathrm{NPK} \\
\left.\mathrm{kg} \mathrm{ha}^{-1}\right)\end{array}$ & $20.54 b$ & 8.74 & $8.00 \mathrm{~b}$ & $41.71 \mathrm{ab}$ \\
\hline $\begin{array}{l}\mathrm{T} 4=30,60,30(\mathrm{NPK} \\
\left.\mathrm{kg} \mathrm{ha}^{-1}\right)\end{array}$ & $22.43 \mathrm{a}$ & 9.51 & $8.97 \mathrm{a}$ & $44.07 \mathrm{a}$ \\
\hline$L S D$ & 1.34 & $N S$ & 0.75 & 4.67 \\
\hline \multicolumn{5}{|l|}{2018} \\
\hline $\begin{array}{l}\mathrm{T} 1=\text { Control (no } \\
\text { fertilization) }\end{array}$ & $16.30 \mathrm{~d}$ & $7.26 \mathrm{c}$ & $6.80 \mathrm{c}$ & $31.00 \mathrm{c}$ \\
\hline $\begin{array}{l}\mathrm{T} 2=30,30,0(\mathrm{NPK} \\
\left.\mathrm{kg} \mathrm{ha}^{-1}\right)\end{array}$ & $17.84 \mathrm{c}$ & $8.33 b$ & $8.03 b$ & $38.54 b$ \\
\hline $\begin{array}{l}\mathrm{T} 3=30,60,0(\mathrm{NPK} \\
\left.\mathrm{kg} \mathrm{ha}^{-1}\right)\end{array}$ & $19.98 b$ & $8.79 b$ & $8.12 b$ & $40.89 b$ \\
\hline $\begin{array}{l}\mathrm{T} 4=30,60,30(\mathrm{NPK} \\
\left.\mathrm{kg} \mathrm{ha}^{-1}\right)\end{array}$ & $23.50 \mathrm{a}$ & $9.88 \mathrm{a}$ & $9.65 \mathrm{a}$ & $45.99 \mathrm{a}$ \\
\hline$L S D$ & 2.11 & 1.02 & 1.20 & 5.01 \\
\hline
\end{tabular}

Means followed by different small letters within column indicate significant differences between the treatments. 
In case of biological yield, the experimental results indicated that effect of mineral nutrition on biological yield was statistically significant during both experimental years (Table 3). In 2017, maximum biological yield (5231 kg ha-1) was observed in treatment where $30,60,30 \mathrm{NPK} \mathrm{kg} \mathrm{ha}^{-1}$ was applied which was statistically at par with treatment having 30, 60, 0 NPK kg ha ${ }^{-1}$ fertilizer application. Lowest quantity of biological crop yield (3933 $\mathrm{kg} \mathrm{ha}^{-1}$ ) was observed in $\mathrm{T} 1$ (control) where no fertilizer was applied to the crop. During 2018 , highest biological yield $\left(5466 \mathrm{~kg} \mathrm{ha}^{-1}\right)$ was observed in treatment where $30,60,30 \mathrm{NPK} \mathrm{kg} \mathrm{ha-1}$ was applied while lowest quantity of biological yield (4035 $\mathrm{kg} \mathrm{ha}^{-1}$ ) was observed in T1 (control) where no fertilizer was applied to the crop.

Harvest index (HI) was also statistically significant during both growing seasons (Table 3). During 2017, highest values of $\mathrm{HI}(22.23 \%)$ was obtained from $\mathrm{T}_{4}$ where fertilizer was applied at the rate of $30,60,30 \mathrm{NPK} \mathrm{kg} \mathrm{ha}{ }^{-1}$ while minimum harvest index $(18.54 \%)$ was noted in plants where no fertilizer application was done (control). In 2018, maximum harvest index $(23.25 \%)$ was observed in treatment where 30, 60, 30 NPK kg ha ${ }^{-1}$ fertilizer was applied while lowest quantity of harvest index $(20.77 \%)$ was obtained from crop where no fertilizer was applied.

Table 4. Seed yield, biological yield and harvest index of mungbean influenced by various nutrients levels.

\begin{tabular}{|c|c|c|c|}
\hline Treatments & $\begin{array}{c}\text { Seed yield } \\
\left(\mathrm{kg} \mathrm{ha}^{-1}\right)\end{array}$ & $\begin{array}{c}\text { Biological } \\
\text { yield }\left(\mathrm{kg} \mathrm{ha}^{-1}\right)\end{array}$ & $\begin{array}{c}\text { Harvest Index } \\
(\%)\end{array}$ \\
\hline \multicolumn{4}{|l|}{2017} \\
\hline $\begin{array}{l}\text { T1= Control (no } \\
\text { fertilization) }\end{array}$ & $729 \mathrm{~d}$ & $3933 c$ & $18.54 \mathrm{c}$ \\
\hline $\begin{array}{l}\text { T2=30, 30, } \\
\left(\text { NPK kg ha }^{-1}\right)\end{array}$ & $891 \mathrm{c}$ & $4466 b c$ & $19.95 \mathrm{c}$ \\
\hline $\begin{array}{l}\text { T3 }=30,60,0 \\
\left(\text { NPK kg ha- }^{-1}\right)\end{array}$ & $1044 b$ & $5029 \mathrm{ab}$ & $20.76 b c$ \\
\hline $\begin{array}{l}\text { T4 =30, 60, } 30 \\
\left(\mathrm{NPK} \mathrm{kg} \mathrm{ha}^{-1}\right)\end{array}$ & $1163 a$ & 5231a & $22.23 \mathrm{a}$ \\
\hline$L S D$ & 52.19 & 753 & 1.42 \\
\hline \multicolumn{4}{|l|}{2018} \\
\hline $\begin{array}{l}\text { T1= Control (no } \\
\text { fertilization) }\end{array}$ & $834 c$ & $4035 c$ & $20.77 \mathrm{c}$ \\
\hline $\begin{array}{l}\text { T2=30, 30, } \\
\left(\mathrm{NPK} \mathrm{kg} \mathrm{ha}^{-1}\right)\end{array}$ & $901 \mathrm{c}$ & $4478 c$ & $20.12 c$ \\
\hline $\begin{array}{l}\text { T3 =30, 60, } \\
(\text { NPK kg ha } \\
\text { (1) }\end{array}$ & $1123 b$ & $5005 b$ & $22.44 b$ \\
\hline $\begin{array}{l}\text { T4 =30, 60, 30 } \\
\left(\mathrm{NPK} \mathrm{kg} \mathrm{ha}^{-1}\right)\end{array}$ & $1271 \mathrm{a}$ & $5466 a$ & $23.25 \mathrm{a}$ \\
\hline$L S D$ & 77.01 & 457 & 0.79 \\
\hline
\end{tabular}

Means followed by different small letters within column indicate significant differences between the treatments.

\section{DISCUSSION}

Integrated nutrient management in mungbean crop is very crucial for production maximization. The study results indicated highest growth, yield and yield components in mungbean where crop received fertilization at the rate of 30:60:30 kg NPK per hectare as compared to no fertilizer application due to balanced application of NPK. Balanced fertilizer application enabled mungbean plants to attain maximum crop growth rate, net assimilation rate, light interception which was later translated into yield production. The results indicated that mungbean gained highest leaf area development along with highest crop biomass when fertilized at the rate of $30 \mathrm{~kg}$ nitrogen per hectare. Results were similar with the judgments of Oscar and Tollenaar (2006) who noted that LAI of crop was significantly increased with increasing nitrogen application. Similarly, Hussain et al. (2011) and Jalali et al. (2017) found that nitrogen enhanced mungbean growth and yield. Moreover, nitrogen $(\mathrm{N})$ is the naturally occurring fundamental element, significantly increase crop growth, control physiological and biochemical procedures in plant (Sinclair and Vades, 2002). It is important for production of DNA, RNA and many growth regulator (Hawkesford et al., 2012) which ultimately enhance the production.

Phosphorus at the rate $60 \mathrm{~kg} \mathrm{ha}^{-1}$ enhance the total biomass, no. of seeds pod ${ }^{-1}$, wight of 1000 seeds photosynthesis and regulated water within plant cells (Garg et al., 2005). Application of $30 \mathrm{~kg} \mathrm{~N} \mathrm{ha}^{-1}$ and $60 \mathrm{~kg} \mathrm{P} \mathrm{ha}^{-1}$ increased total dry matter as indicated by the results of this experiment (Asaduzzaman et al., 2008; Hussain et al., 2011). Results indicated highest value of harvest indext at $60 \mathrm{~kg} \mathrm{ha}^{-1}$ which was in accordance to Akhter et al. (2003) who indicated that phosphorus application increases harvest index in mungbean. Additionally, phosphorus play significant role in ATP, nucleic acid, flowering, and controls metabolism (Iqbal and Chauhan, 2003, produce proteins, phospholipids and phytin in mungbean. It is indiacted that Seeds and fruits with large amount of phosphorus promoted crop growth, development and build up resistance against diseases (Raboy, 2003). Plant dry matter production and grain yield can be increased by addition of phosphorus in mungbean (Iqbal et al., 2012; Shah et al., 2006).

Results also indicated that application of potassium along with nitrogen and phosphorous enhanced mungbean growth, yield and yield components which was inaccordance with previous studies (Bukhsh et al., 2011; Arif et al., 2008). Actually, potassium has many functions related to plant such as it improves the mechanism of photosynthesis, maintains turgor pressure of cell and play important role in opening and closing of stomata (Garg et al., 2005) which further can be translated into yield enhancement which was observed in the current study.

Overall, NPK plays very critical role of improving growth, yield parameters, seed yield, biological yield and harvest index in mungbean crop (Oscar and Tollenaar, 2006; Asaduzzaman et al., 2008; Bukhsh et al., 2011; Hussain et al., 2011). The results also indicated an increasing trend of growth, yield and yield components during 2018 growing 
season as compared to 2017 because legume crops have the capacity to create a mutual association with particular microbes, fixing biological nitrogen in root nodules that provides nitrogen to plants (Mandal et al., 2009; Mahmood and Athar, 2008) and also increase soil fertility with passage of time and was the possible reason of yield increase from 2017 to 2018.

Conclusion: Fertilizer application in balance amount is very important to raise the productivity of legume crops under semi-arid conditions. Mungbean production is increased with balance quantity of nitrogen $(\mathrm{N})$, phosphorous $(\mathrm{P})$ and potassium $(\mathrm{K})$ at the rate of $30: 60: 30 \mathrm{~kg}$ per hectare under semi-arid environment. Farmers can be convinced to apply a limited quantity of fertilizer to the legume crops and is important to change their perception of no fertilizer application to legume crops. This will directly enhance the overall farm income and soil fertility of small landholding farms over time.

Acknowledgements: The authors acknowledge funding sources (Kissan Forum, DGK) and the support of the staff at the Agronomy Farm, University of Agriculture, Faisalabad for conducting the experiment and data acquisition.

\section{REFERENCES}

Ansari, A.H., A.A. Kakar, A.B. Tareen, A.R. Barecht and G.M. Kakar. 2000. Planting pattern and irrigation level effects on growth, yield components and seed yield of soybean (Glycine max L.). Pak J. Agric. Sci. 4: 37-61.

Arif, M., M. Arshad, A. Khalid and A. Hannan. 2008. Differential response of rice genotypes at deficit and adequate potassium regimes under controlled conditions. Soil Environ. 27: 52-57.

Asaduzzaman, M.D., M.D.F. Karim, M.D.J. Ullah and M. Hasanuzzaman. 2008. Response of mungbean (Vigna radiata L.) to nitrogen and irrigation management. American-Eurasian J. Sci. Res. 3: 40-43.

Bukhsh, M.A.A.H.A., R. Ahmad, A.U. Malik, S. Hussain and M. Ishaque. 2011. Profitability of three maize hybrids as influenced by varying plant density and potassium application. J. Animal and Plant Sci. 21: 42-47.

Garg, B.K., U. Burmin and S. Kathju. 2005. Physical aspects of drought tolerance in cluster bean and strategies for yield improvement under arid conditions. J. Arid Legumes 2: 61-66.

Govt. of Pakistan. 2017. Economic survey of Pakistan 20162017. Planning and Development division. Finance Wing. Government of Pakistan. Ministry of Finance, Islamabad.

Hawkesford, M., W.Horst, T. Kichey, H. Lambers and J. Schjoerring. 2012. Functions of macronutrients. In: Marschner P (ed.), Marschner's, mineral nutrition of higher plants. School of Agricuture, food and wine, The university of Adelaide, Australia, pp. 135-189.

Hoque, A.T.M., M.K. Hossain, M. Hossain, M.M Hoque. 2004. Effect of inorganic fertilizers on the initial growth performance of Anthocephalus chinensis rich. Ex. Walp. seedlings in the nursery. J.Appl. Sci. 4: 477-485.

Hozayn, M., M.S. Zeidan, A.E. Lateef and M.S.A.E. Salam. 2007. Performance of some mungbean (Vigna radiata L.) genotypes under late sowing condition in Egypt. Res. J. Agric. Biol. Sci. 3: 972-978.

Hunt, R. 1978. Plant growth analysis. Edward Arnold, U.K. pp. 26-38.

Hussain, M., S. Ijaz and M. Bibi. 2006. Accumulation of nutrients and metal ions by two mungbean (Vigna radiata L.) cultivars treated with copper and lead. Bull. Environ. Contam. Toxicol. 77: 581-589.

Hussain, N., M. Mehdi and R.H. Kant. 2011. Response of nitrogen and phosphorus on growth and yield attributes of black gram (Vigna mungo L.). J. Agric. Sci. 2: 334336.

Iqbal, M.A., M. Khalid, S.M. Shahzad, M. Ahmad, N. Solemanan andN. Akhtar. 2012. Integrated use of Rhizobium leguminosarum, plant growth promoting rhizobacteriam and enriched compost for improving growth, nodulation and yield of lentil. Chil. J. Agric. Res. 72: 104-110.

Iqbal, R.M. and H.Q.I. Chauhan. 2003. Relationship between different growth and yield parameters in maize under varying level of phosphorus. J. Biol. Sci. 3: 921-925.

Jalali, M.N., A.K. Choudhary, M.Q. Mangle, M.A. Omari, H. Hamayon, S.R. Ghafari and A. Dass. 2017. Respons of different nitrogen levels on growth and yield of mungbean (Vigna radiata L.) in semiarid region of Kandahar Afghanistan. Inter. J. App. Res. 3: 102-106.

Khattak, G.S.S., M. Ashraf and M.S. Khan. 2004. Assessment of genetic variation for yield and yield components in mungbean (Vigna radiata L.) using generation mean analysis. Pak. J. Bot. 36: 583-588.

Mahmood, A. and M. Athar. 2008. Cross inoculation studies: Response of Vigna mungo to inoculation with rhizobia from tree legumes growing under arid environment. J. Environ. Sci. Technol. 5: 135-139.

Malik, B.A 1994. Grain legume. In: Bashir E, Bantel R (ed.), Crop production. Islamabad, Pakistan: National Book Foundation, pp. 277-328.

Mandal, S., M. Mandal and A. Das. 2009. Stimulation of indole acetic acid production in a Rhizobium isolate of Vigna mungo by root nodule phenolic acids. Arch. Microbiol. 191: 389- 393.

Mondal, M.M.A., M.S.A. Fakir, A.S.Juraimi, M.A. Hakim, N.M. Islam and A.T.M. Shamsuddoha. 2011. Effect of flowering behavior and pod maturity synchrony on yield of mungbean (Vigna radiata L.). Aust. J. Crop Sci. 5: 945-953. 
Oscar, R.V. and M. Tollenaar. 2006. Effect of genotype, nitrogen, plant density and row spacing on the area-perleaf profile in maize. Agron. J. 98: 94-99.

Raboy, V. 2003. Molecules of interest: myo-inositol-1, 2, 3, 4, 5, 6-hexakisphosphate. Phytochemist. 64: 1033-1043.

Shah, S.K.H., M. Aslam, P. Khan, M.Y. Memon, M. Imtiaz, S.H. Siddiqui and Nizamuddin. 2006. Effect of different methods and rates of phosphorus application in mungbean. Soil Environ. 25: 55-58.

Shil, S. and P.K Bandopadhyay. 2007. Retaining seed vigor and viability of mug bean by dry dressing treatments. J. Food Leg. 20: 173-75.
Sinclair, T.R. and V. Vades. 2002. Physiological traits for crop yield improvement in low $\mathrm{N}$ and $\mathrm{P}$ environments. Plant Soil 245: 1-15.

Singh, A.K., M.K. Meena, R.C. Bharati and R.M. Bharati. 2013. Effect of sulphur and zinc management on yield, nutrient uptake, changes in soil fertility and economics in rice (Oryza sativa) lentil (Lens culinaris) cropping system. Ind. J. Agric. Sci. 83: 344348. 